\title{
JEROME KARLE (1918-2013)—Nobel laureate; Charter member of the Editorial Board of Structural Chemistry
}

\author{
Istvan Hargittai • Magdolna Hargittai
}

Published online: 22 September 2013

(C) Springer Science+Business Media New York 2013

\begin{abstract}
Jerome Karle (1918-2013) had to overcome adversities before he acquired the education he strived to get. He did pioneering work in modernizing the gas-phase electron diffraction technique of molecular structure determination. Drawing on this experience, he and Herbert Hauptman jointly came to a seminal discovery that solved the phase problem in crystal structure determination by $\mathrm{X}$-ray diffraction. All along, he enjoyed close cooperation with his wife, the most distinguished scientist Isabella Karle. Jerome Karle was a revered colleague and a faithful friend.
\end{abstract}

Keywords Jerome Karle · Isabella Karle · Gas electron diffraction $\cdot$ Phase problem $\cdot$ X-ray crystallography

Jerome Karle (Fig. 1) was born in 1918 in Coney Island, a part of Brooklyn, New York. When in 2009 he retired from the US Naval Research Laboratory in Washington, DC, he was Chief Scientist of the Laboratory for the Structure of Matter. He received his M.A. at Harvard University (in biology) in 1937 and his M.S. (in physical chemistry) at the University of Michigan in Ann Arbor in 1941, and finished his work there for the Ph.D. degree in 1943. In between his studies at Harvard and graduate work at the University of Michigan, he worked at the New York State Health

I. Hargittai $(\bowtie) \cdot$ M. Hargittai

Department of Inorganic and Analytical Chemistry,

Budapest University of Technology and Economics, PO Box 91, Budapest 1521, Hungary

e-mail: istvan.hargittai@gmail.com

M. Hargittai

e-mail: hargittaim@mail.bme.hu
Department where he developed, as one of his chores, the standard method used for testing the amount of fluoridation that was applied to water supplies. He worked on the Manhattan Project at the University of Chicago in 1943 and in 1944. He returned to the University of Michigan to work on a project for the Naval Research Laboratory (NRL). In 1946, he and his equally distinguished wife, Isabella Karle, became members of the NRL. Among many other distinctions, he was a member of the National Academy of Sciences of the U.S.A., served as President of the International Union of Crystallography, and received the Nobel Prize in Chemistry in 1985, jointly with Herbert Hauptman, "for their outstanding achievements in the development of direct methods for the determination of crystal structures." In 1989, he was one of the charter members of the new periodical Structural Chemistry, and the fledgling journal greatly benefited from his active support.

We were in friendly and collegial interactions with Jerome and Isabella Karle for decades (Fig. 2); from the early 1970s, we enjoyed our get-togethers at meetings and visited each other in our homes. We learned a great deal about the Karles over the years; then on two separate occasions, we recorded more formal conversations with them, in 2000, with Isabella, and in 2003, with Jerome. Jerome was not very eager to share some of his experiences of his youth, though he found them important so that others might find them instructive. Some of these experiences are quoted below that have been largely absent in the obituaries and reminiscences we have seen about Jerome.

Jerome's paternal grandfather was a painter in the artistic sense. He specialized in decorating ceilings both with paintings and with reliefs. Almost everybody on Jerome's father's side of the family had artistic inclinations, except Jerome's father and one of his sisters. Jerome's father was born in 1882 in Poland, and he came to the 


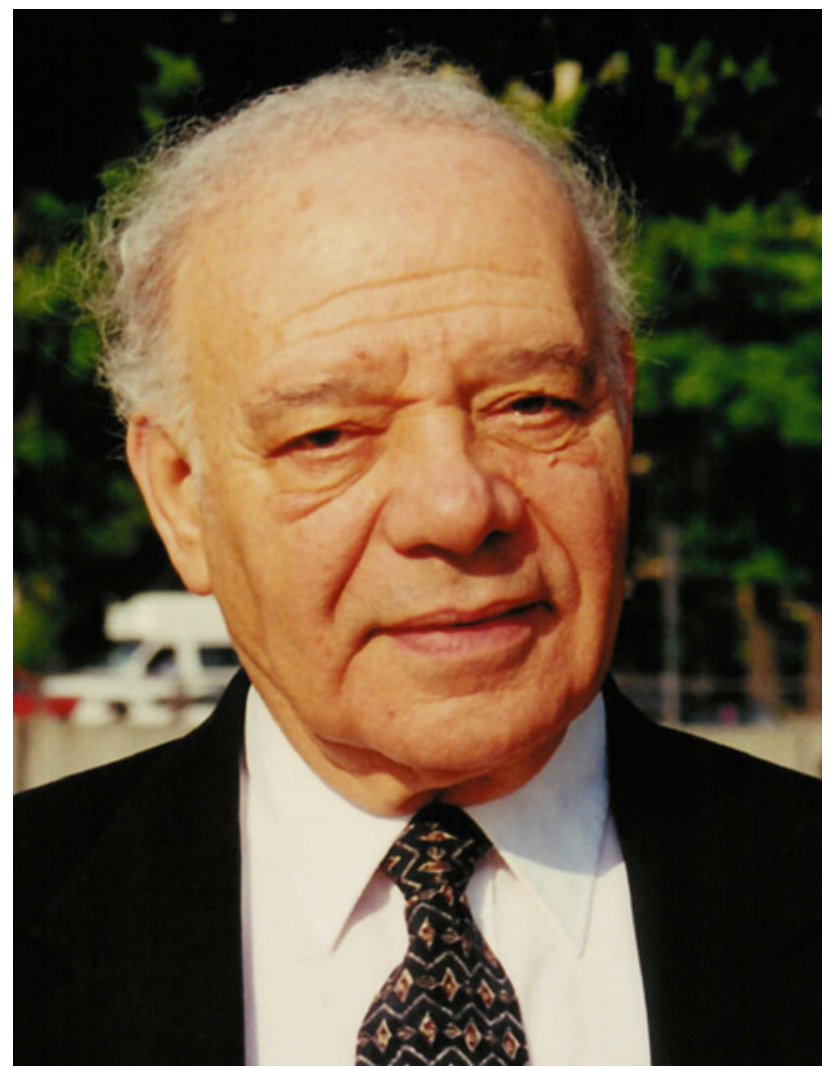

Fig. 1 Jerome Karle in 2000 in Washington, DC (photo by I. Hargittai)
United States as a small child. On Jerome's mother's side, there was not much artistic inclination. Jerome's mother was the fourth child in her family. Her father had to face a difficult situation because his wife, Jerome's maternal grandmother, died, leaving Jerome's grandfather alone with his four children. He felt that he could take care of three, but not of all four. So the smallest child-she would become Jerome's mother-was adopted by members of her extended family, by the name of Kun, who had come to the US from Budapest. Jerome's mother was very talented and she was an excellent pianist. Jerome also learned to play.

Jerome's immediate family environment was not conducive for him to become interested in science, but when he was seven or eight years old, his mother took him to a science museum. This hands-on museum captivated Jerome's attention and imagination. The museum did not exist for long, but long enough to set Jerome on his course for science. He read popularized science books and he wrote book reports that caught his teachers' attention, and when he was nine years old he qualified for pushing ahead. Jerome graduated from the eighth grade before he was eleven years old. Then, he went to Abraham Lincoln High School, followed by City College of New York, from which he graduated when he was 19 years old.

So far, Jerome's path was smooth sailing, but rough times were ahead. He was Jewish and it proved impossible for him to get into medical school. This was a painful story

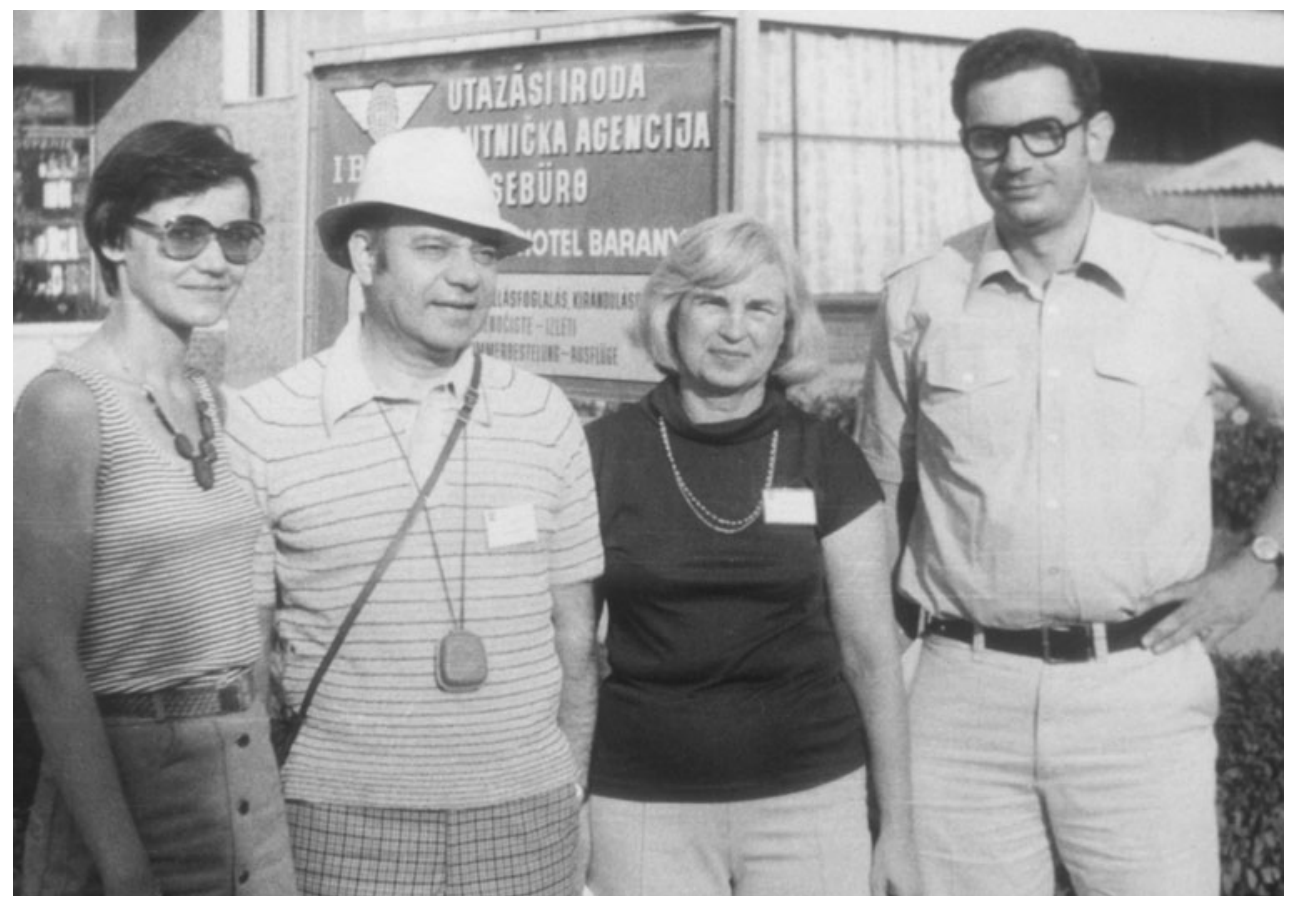

Fig. 2 The Karles and the Hargittais (the two Karles in the middle) in 1978 in Pécs, Hungary 
for Jerome to remember, and he was hesitant whether it was proper for him to speak about it, but he decided that he should.

"I went to Harvard and spent a year there obtaining a master's degree in biology. I had the illusion that being a good student was all that was necessary to get admitted to medical school. I applied to Harvard and some other places and, of course, I was turned down. I wanted to try again early the next year and I was allowed to have a conversation with the Dean of the [Harvard] Medical School. The only thing I got from him was a harangue. He said 'We have enough Jews in Massachusetts; we don't need any from New York City'. He was not at all interested in my record as a student. For example, when I graduated from City College I received the first award given at graduation for "excellence in the natural sciences" " [1].

Jerome did not give up.

"I had applied to various graduate schools just to do graduate work and I was turned down by all of them. So I wasn't doing anything. Then there was just a stroke of luck. In the summer of 1938 I was working in Coney Island and a good friend of mine, with whom I still communicate, told me that exams were forthcoming for civil service jobs in the New York State Health Department. I took the exam and I had the highest grade among those they accepted. There was a rule that after a certain period, perhaps three months, the Health Department could not dismiss anyone without an explanation. I stayed for about two years. I learned only later that they had wanted me to leave, along with the rest of the people who arrived when I did, but my boss said that if they tried to dismiss me, he would not accept that and that he needed me for his work. This fine gentleman's name was F. Wellington Gilcrease. He remained my good friend and we kept in touch until the end of his life. I did not know that he saved me from dismissal until I left to go to the University of Michigan. During those two years, I was saving up money as I knew I couldn't get any money from graduate school. At that time, someone told me that if I went to the University of Michigan, I would be treated properly. That is why I went there. After the first year, I was funded to continue my education at the University of Michigan. After that I have never experienced any anti-Semitism." [1]

Jerome met his future wife, Isabella, who was a fellow student, at Michigan. Their cooperation evolved during the years. Initially they both did about equal amounts of experimental work, but gradually Jerome moved more and more toward theory. They both did their doctoral work under the supervision of L. O. Brockway. Brockway had been a Linus Pauling disciple who in the 1930s worked out the technique of Fourier-transform radial distribution technique with Pauling for an improved analysis of electron diffraction data. The two Karles advanced greatly the technique of gas-phase electron diffraction during the second half of the 1940s, especially by evaluating the impact of molecular motion on the experimental distributions, both the molecular intensities of electron scattering and the radial distributions (a misnomer), essentially, the probability density distribution of intramolecular internuclear distances. The present authors learned a great deal from the Karles' classic papers at the beginning of their research careers.

At the Naval Research Laboratory, the Karles established one of the world's most active and most innovative gas-phase electron diffraction laboratories, including the construction of new and improved experimental apparatus, and, of course, always up-to-date computational techniques. The innovations and the careful evaluation of the techniques of analysis in electron diffraction proved beneficial much beyond the molecular structure determination by electron diffraction. Jerome was familiar with the X-ray diffraction field and attended meetings where both X-ray diffraction and electron diffraction were discussed.

Jerome soon recognized that because it was supposed that the phases of X-ray diffraction could not be extracted from the experimental data, a large portion of experimental information was lost and the unambiguous determination of crystal molecular structures was hindered. Jerome started interacting with Herbert Hauptman who had also joined NRL and was even more mathematically oriented than Jerome [2]. Their joint research resulted in discovering what has been known as the direct methods of X-ray crystallography that, on the one hand, have greatly expanded the scope of structures that are possible to determine and, on the other, have greatly enhanced the reliability and accuracy of crystal structure determinations. The technique is by now well known, and the readers of Structural Chemistry have had a unique opportunity to be introduced to it directly by its creators, Herbert Hauptman [3] and Isabella and Jerome Karle [4]. Another principal contributor to the technique was David Sayre [5]. Isabella Karle did pivotal work in demonstrating the applicability of the direct methods and this was especially beneficial as crystallographers were rather slow in recognizing the new perspectives that the Karles and Hauptman were offering [6]. At one point, there was a paper in Acta Crystallographica in which two renowned crystallographers posed the question "Have Hauptman and Karle Solved the Phase Problem?" This was the title of the communication and the paper was devoted to showing that the answer to this question was an emphatic "no!" [7]. Not only did the two authors eventually come around; they became two of the most devoted and prolific researchers to employ the direct methods.

One of us (IH) remembers: One October day in 1985, our guest, the well-known Italian crystallographer Aldo 
Domenicano, and I were sitting in my office in Budapest when the telephone rang and it was a reporter from Radio Budapest. He asked me about the new chemistry Nobel laureates, Herbert Hauptman and Jerome Karle and about their achievement. I must admit that both Aldo and I were surprised by the news. We both knew Herb and Jerry and admired them, but had not thought about a possible Nobel Prize for them. We needed some time to absorb the information, but once it sank in, we had no doubt whatsoever that their award was amply justified. Looking back, perhaps their natural modesty was what made the Nobel announcement appear unexpected rather than any doubt about the importance of their discovery.

Jerome had only one regret about the Nobel Prize- that Isabella was not among the awardees. She would have deserved it, but perhaps others would have just as well. The selection of Hauptman and Jerome Karle was beyond reproach; filling the third slot of the available three places would have become inevitably controversial, whereas nobody has ever criticized the actual choice. For Jerome, among other benefits, the Nobel Prize provided a welcome opportunity to reach out to a broader audience than they could before. Jerome never had a university position and NRL while providing ideal conditions for his research, not being an educational institution did not offer the possibility for a researcher, however distinguished he or she was, to be surrounded all the time by young students. Jerome was open-minded and generous and in subsequent years indulged in enhanced visibility whereas he could always withdraw into the quiet of his NRL laboratory.

As for his personal traits, we can both attest to his having been a most generous and helpful human being; broadly interested in a wide variety of topics, including the arts. IH: I experienced Jerome's friendship already at the time when he was already a world-renowned authority and I was hardly more than a beginner in science. I had known about the works of the Karles, but our first personal meeting took place in the early 1970s. I was on my way to Austin, Texas, and the Karles invited me to their home for three days. I learned a great deal of science mainly from Jerome during those three days. What is more remarkable though, and I almost took it for granted, that Jerome toured with me all the major museums and galleries in Washington, DC, and spent a great deal of time introducing me to their exhibits.

Jerome Karle was an outstanding scientist, a distinguished contributor to the scientific revolutions of the twentieth century, and a remarkable human being. Not only will the fruits of his discoveries, but also the sense of his personality, be long remembered.

\section{References}

1. Hargittai I, Hargittai M (2006) Jerome Karle. In: Candid Science VI: More conversations with famous scientists. Imperial College Press, London, pp 422-437

2. Hargittai I (2003) Herbert A Hauptman. In: Hargittai M (ed) Candid Science III: More conversations with famous chemists. Imperial College Press, London, pp 292-317

3. Hauptman HA (1990) Struct Chem 6:617-620

4. Karle I, Karle J (2005) Struct Chem 16:5-16

5. Sayre D (2002) Struct Chem 13:81-96

6. Hargittai I, Hargittai M (2006) Isabella L. Karle. In: Candid Science VI: More conversations with famous scientists. Imperial College Press, London, pp 402-421

7. Cochran W, Woolfson MM (1954) Acta Crystallogr 7:450-451 